\title{
The Influence of Reading Ability and Learning Interests on Learning Outcomes in Elementary School
}

\author{
Suminah $^{1 *)}$, Happy Fitria ${ }^{2}$, Syaiful Eddy ${ }^{2}$ \\ ${ }^{I}$ SD Negeri 3 Jirak \\ ${ }^{2}$ Universitas PGRI Palembang \\ "Corresponding author. Email: suminahbrojol.sp.d@gmail.com
}

\begin{abstract}
The goals of this study were to examine: 1) the impact and influence of Reading Ability Level on Student Learning Outcomes, 2) the impact and influence of Learning Interest on Student Learning Outcomes, 3) the impact and influence of Reading Ability Level and Learning Interest collectively on Student Learning Outcomes. The observation and discussion of the research stated that: 1) there was an effect of Reading Ability Level on Student Learning Outcomes; 2) there is an effect of learning interest on student learning outcomes; and 3) there is an influence between Reading Ability Level and Learning Interest simultaneously on Student Learning Outcomes. We hope that this study will give a
\end{abstract}

Keywords: Reading skill level, Interest, Learning outcomes.

\section{INTRODUCTION}

Education is the most important thing in human life because every human being has the right to receive and hopes to always develop in education. In line with the opinion of Utamy [1], education is the most effective and efficient means of transforming science, culture and so on from one generation to the next. It is in line with the opinion of Fitria [2] that education is one of the important things that affects the development and progress of a nation, considering that education is a strategic means and vehicle in human resource development. Quality human resources are investment capital for the development and growth of the country

In accordance with this, Indonesia needs to position itself as a nation with a literacy culture, so development efforts need to be made, both through formal and nonformal education channels. Development through formal education starts from elementary schools which function as cultural centers and literacy culture. So, schools must equip graduates with adequate basic skills and abilities [3].

Reading is one of the four important language skills in addition to the other three language skills. Reading has an important role in human life, because reading is a communication tool that is indispensable in a society. According to Tarigan [4] reading is a transform that is performed and used by a reader to get information and messages, which the author intends to send through the written language or media of words.

The Generally the teachers teach reading only to the surface, not giving students the opportunity and freedom to understand the contents of the reading from their own point of view, and are unable to increase passion for the reading culture. As stated by Alhusaini [5] teachers are the second parents in schools who are given the mandate to educate, train, guide and direct the potential of students in realizing what they have dreamed of. Teachers as educators must be able to provide the best possible education to students, so that educational goals can be achieved optimally. There are many factors that inhibit students from practicing reading, some of which are interest. According to Slameto [6] interest is a feeling of preference and attachment to something or activity.

Based on the results of observations on pre-research activities at State Elementary School (SD Negeri) 1 Jirak, SD Negeri 3, and SD Negeri Bangkit Jaya in telling storytelling in Indonesian, the researcher found that student interest in learning was still low, this could be characterized by students in receiving learning, students still ignoring assignments given by the teacher. Lack of deepening of the material outside the learning hours and other characteristics identify the low interest in learning and have an impact on values below the Minimum Completeness Criteria. 
Interest in learning is important so that students can successfully learn a science and improve student learning outcomes. According to Purwanto [7] interest affects learning outcomes. In line with the opinions Putri [8] that the learning outcome is necessary to design a study that familiarizes the student to construct his thoughts well with teachers, friends and the material itself. Furthermore, according to [2] that to increase student interest, teachers are asked to provide innovative lessons that can encourage learners to study more optimally, both independent learning and in classroom learning with innovative methods, props and other learning media.

\section{METHODS}

This study uses a quantitative descriptively by using double correlation (multiple correlation), which is a number that indicates the direction and strength of the relationship between two variables independent together with one or more variable dependent . Arikunto [9] said that the quantitative approach is the approach used by researchers in research by measuring variable indicators, so that an overview and conclusions of the research problem can be obtained.

The population in this study were all SD Negeri Kecamatan Jirak Jaya, especially students in grade 2, totaling 17 State SDs consisting of 2 State SDs with Accreditation A, 12 Public SDs with B Accreditation, and 12 Public SDs with C Accreditation. as many as 3 State SD .

The total sample taken was 67 students, especially students in grade 2 of 3 Public Elementary Schools consisting of SD Negeri 1 Jirak with 27 students, SD Negeri 3 Jirak with 28 students, and SD Negeri Bangkit Jaya with the total number of 12 students. Data were collected using a Likert scale model questionnaire. The data analysis techniques used descriptive quantitative analysis technique and multiple regressions.

\section{RESULTS AND DISCUSSION}

\section{The Effect of Reading Ability Level on Student Learning Outcomes}

This study showed that the rate of Literacy (X1) to the Student Learning Outcomes (Y) after analysis of data obtained by value $t_{\text {arithmetic }}(10.146)>t_{\text {table }}(3.14)$ at the significant level of $5 \%$ and a probability value $(\mathrm{p})$ of $0.000<0.05$. From these results it can be summarized that there is a significant impact of the Reading Ability Level (X1) on Student Learning Outcomes (Y) in SD Negeri Kecamatan Jirak Jaya. From this statement it can be said that $\mathrm{Ho}$ is rejected and $\mathrm{Ha}$ is accepted. In addition, it also explains the percentage of the influence of the Reading Ability Level (X1) on Student Learning Outcomes (Y) which is called the coefficient of determination which is the result of squaring R.From the table above, it is obtained the coefficient of determination (Adjust $R$ Square) of 0.607 which contains the meaning that the influence of Reading Ability Level (X1) on Student Learning Outcomes (Y) is $60.7 \%$; while the remaining $39.3 \%$ is influenced by other variables not examined in this study.

The findings of this study are in line with the results of research by Rudyanto [10] entitled "The Effect of Reading Comprehension Ability on Mathematics Learning Achievement on the Subject of Class IV Story Questions". The results of this study note that the coefficient of determination obtained is $52.54 \%$ or 0.5254 and the rest is influenced by other variables. So, it can be concluded that there is an influence of the ability to read smoothly on mathematics learning achievement on the subject of the fourth grade students of SDN 2 Kertosari during the 2016/2017.

Furthermore, the results of research by Fitriah [11] entitled, "The Relationship between Textbook Reading Ability and Critical Thinking Skills with Learning Outcomes of Islamic Education". The results indicate that the level of learning outcomes is high and satisfying, reaching $73.55 \%$. Fourth, a significant and positive relationship between the ability to read textbooks and the learning outcomes of Islamic Education subjects. Fifth, there is a positive and significant relationship between critical thinking skills and learning outcomes in Islamic Education subjects. Sixth, there is a positive and significant relationship between the ability to read textbooks and critical thinking skills together with the results of Islamic Education lessons.

States that reading skills are complex abilities require cooperation between a numbers of abilities [12]. To be able to read a reading, students must be able to use the knowledge they already have. In connection with this statement, it can be said that reading is the main thing in education, if the teacher or student cannot read, then there is no information and knowledge that can be shared or obtained.

\section{The Influence of Learning Interests on Student Learning Outcomes}

Results showed that the Interest of Learning (X2) on Student Learning Outcomes (Y) after analysis of data obtained by value $\mathrm{t}_{\text {arithmetic }}(14.078)>\mathrm{t}_{\text {table }}$ (3.14) at the significant level of $5 \%$ and a probability value (p) of $0.000<0,05$. From these results it can be concluded that there is a significant effect of Learning Interest (X2) on Student Learning Outcomes (Y) at SD Negeri Kecamatan Jirak Jaya. From this statement it can be said that $\mathrm{Ho}$ is rejected and $\mathrm{Ha}$ is accepted. In addition, it also explains the percentage of influence of Learning Interest (X2) on Student Learning Outcomes (Y) which is called the coefficient of determination which is the 
result of squaring R.From the table above, it is obtained the coefficient of determination (Adjusted $R$ Square) of 0.749 which implies that the influence of Learning Interest (X2) on Student Learning Outcomes (Y) amounted to $74.9 \%$; while the rest $25.1 \%$ is influenced by other variables that was not examined in this study.

The findings of this study are in line with the results of research by [13] entitled, "The Relationship Between Reading Interest and Learning Achievement in Productive Subjects in SMK". The results of this study show that the results of the correlation test between reading interest and learning achievement in productive subjects are 0.5. This figure shows the relationship between reading interest and learning achievement in productive subjects at SMK, which is in the medium category and has a positive relationship.

According to Slameto [6] what is meant by learning interest is a feeling of preference and a sense of interest in something without being asked. Interest in learning is basically the acceptance of a relationship between oneself and something outside oneself. The stronger the relationship, the greater the interest in learning one has.

\section{The Impact and Effect of Reading Ability Level and Learning Interest}

The results showed that the Reading Ability Level (X1) and Learning Interest (X2) on Student Learning Outcomes (Y) after the data analysis was carried out, the calculated $F \quad$ value (14.235)> $\quad F_{\text {table }}$ (1.99) was obtained. Then the test obtained the value of Sig = $0.000<0.05$. Hypothesis test results showed that there is a significant effect simultaneously Reading Ability Level (X1) and Learning Interest (X2) on Student Learning Outcomes (Y). In addition, it also explains the percentage of influence of the independent variables (Reading Ability Level and Learning Interest) on the dependent variable (Student Learning Outcomes) which is called the coefficient of determination which is the result of squaring R. From the table above, the coefficient of determination (Adjust R Square ) of 0.758 which means that the influence of the independent variables (Reading Ability Level and Learning Interest) on the dependent variable (Student Learning Outcomes) is $75.8 \%$; while the remaining $24.2 \%$ is influenced by other variables not examined in this study.

The findings of this study are in line with the results of research by Wahidy [14]. The results of this study show that the results of observations during the learning process of reading comprehension using the talking stick learning model; it appears that the reading process of students' understanding is very active. The results of the truth testing of the hypothesis that the author proposes show that $\mathrm{t}$-count $>\mathrm{t}$-table, namely $3.37>$ 1.67, this means that there is an effect of the talking stick learning model on the reading comprehension ability of grade VIII students at SMP
PGRI Sukamoro, Banyuasin Regency, the truth is proven and acceptable. This results are in line with Dilla's opinion in reading activities are based on three basic skills, namely recording, decoding, and meaning [15].

\section{CONCLUSION}

In summary, the study shows that: 1) there is an effect of Reading Ability Level on Student Learning Outcomes; 2) there is an effect of learning interest on student learning outcomes; and 3) there is influence between the rate of Reading Ability and Interest in Learning together towards Learning Outcomes with the value $\mathrm{F}_{\text {arithmetic }}(14.235)>\mathrm{F}_{\text {table }}(1.99)$ as well as the significant value of $0.000<0.05$ indicated by the regression line $\mathrm{Y}=16,950+0.189 \mathrm{X} 1+$ 0.634X2. Reading Ability Level (X1) and Learning Interest (X2) were able to influence Student Learning Outcomes (Y) by $75.8 \%$; while the remaining $24.2 \%$ is affected by other variables not studied in this research.

\section{REFERENCES}

[1] Utamy, R, Ahmad, S., Eddy, S. (2020). Implementasi Manajemen Sumber Daya Manusia. Journal of Education Research, 1(3), 2020, Pages 226-236.

[2] Fitria, H, Subekti, H.A, Nubaiti, Masilawati. (2020). Pemanfaatan Video Conference Sebagai Media Permbelajaran Interaktif Pada Mata Pelajaran Produktif Di Sekolah Menengah Kejuruan. Jurnal Prosiding Seminar Nasional, Pendidikan Program Pascasarjana Universitas Pgri Palembang 10 Januari 2020. Seminar Nasional Pendidikan PPS Universitas PGRI Palembang 2020.

[3] Zulela. (2013). Pembelajaran Bahasa Indonesia Apresiasi Sastra di Sekolah Dasar. Bandung: Remaja Rosdakarya.

[4] Tarigan, H.G. (2013). Membaca Sebagai Suatu Keterampilan Berbahasa. Bandung: Angkasa Bandung.

[5] Alhusaini, A, Kristiawan, M., dan Eddy, S. (2020). Pengaruh Motivasi Kerja dan Disiplin Kerja terhadap Kinerja Guru. Jurnal Pendidikan Tambusai. SSN: 2614-6754 (print) ISSN: 2614 3097 (online) Hal. 2166-2172 Volume 4 Nomor 3 Tahun 2020.

[6] Slameto. (2013). Belajar dan Faktor-faktor yang Mempengaruhinya. Jakarta: PT Rineka Cipta.

[7] Purwanto, N. (2014). Psikologi Pendidikan. Bandung: PT. Remaja Rosdakarya. 
[8] Putri, D.N.A.O, Lian, B., Pramika, D. (2019). Pengaruh Model Pembelajaran Concept Attainment Terhadap Hasil Belajar Siswa Pada Mata Pelajaran Ekonomi di SMA Srijaya Negara Palembang. Jurnal Neraca, Vol.3 No.1,Juni 2019: 77-88.

[9] Arikunto, S. (2010). Prosedur Penelitian Suatu Pendekatan Praktik. Jakarta: Rineka Cipta.

[10] Rudyanto, H.E. (2017). Pengaruh Kemampuan Membaca Pemahaman Terhadap Prestasi Belajar Matematika Pada Pokok Bahasan Soal Cerita Kelas IV. Jurnal Online. Dosen Prodi PGSD Universitas PGRI Madiun. Jurnal Kependidikan Dasar Islam Berbasis Bisnis. Volume 2, No. 2, Tahun 2017.

[11] Fitriah, D. (2017). Hubungan Kemampuan Membaca Buku Teks dan Keterampilan Berpikir Kritis Dengan Hasil Belajar Pendidikan Agama Islam. Jurnal Online. Studi Didaktika: Jurnal Ilmiah Bidang Pendidikan Vol. 11, No. 1, 2017; ISSN 1978-8169 Fakultas Tarbiyah dan Keguruan UIN “SMH” Serang, Banten.

[12] Akhadiah, S. (2012). Pembinaan Kemampuan Menulis Bahasa Indonesia. Jakarta: Erlangga.

[13] Sabriyadi. (2015). Hubungan Antara Minat Baca Dengan Prestasi Belajar Pada Mata Pelajaran Produktif Di SMK. Jurnal Online. Journal of Mechanical Engineering Education, Vol. 2, No. 1. Hal. 24-129.

[14] Wahidy, A. (2016). Pengaruh Model Pembelajaran Talking Stick Terhadap Kemampuan Membaca Pemahaman Siswa Kelas VIII SMP PGRI Sukamoro Kabupaten Banyuasin. Jurnal Prosiding Universitas PGRI Palembang. Jurnal Dosen Universitas PGRI Palembang Edisi 6.

[15] Dilla, F. (2017). Pengaruh Tingkat Keterampilan Membaca Bagi Kecerdasan Peserta Didik. Jurnal Online. Mahasiswa Universitas Bung Hatta. Program Studi Pendidikan Bahasa dan Sastra Indonesia. Fakultas Keguruan dan Ilmu Pendidikan 